\title{
Exploration on Fulfillment Approaches of Corporate Social Responsibility under the COVID-19 Epidemic
}

\author{
Wanzhen Li \\ School of Economics, ShenYang University, ShenYang, LiaoNing, China
}

\begin{abstract}
Objectives: With the development of the times, Corporate managers often face decisions concerning the characteristics of corporate social responsibility (CSR), including handling employee relationships, product pricing and product quality. In the critical period of China's fight against the COVID-19 epidemic, the economic development of enterprises is facing unprecedented challenges. In such a context, some enterprises might prioritize economic benefits in the development and ignore their CSRs. This individual phenomenon will not only restrict the growth of enterprises, but also exert an adverse effect on social development. The exploration of approaches for fulling CSR becomes particularly important under the background of the COVID-19 epidemic. Methods: This paper mainly uses AHP (Analytical Hierarchy Process) to analyze.Results: Hence, this paper attempted to analyze social responsibilities that should be taken on by corporates under the COVID-19 epidemic. Moreover, a corporate social responsibility evaluation system was also established through analyzing the actual situation of some CSR deficiencies in the context of COVID-19 using the AHP method based on the understanding of the CSR concept in literature at home and abroad. In this way, approaches for fulfilling CSR under the COVID-19 epidemic were explored.Conclusions: A CSR evaluation index system is established under the COVID-19 epidemic, so as to force and drive enterprises to persist the enterprise's voluntary fulfillment of CSR for a long time.
\end{abstract}

Keywords: Corporate social responsibility, absence of responsibility, AHP (Analytic Hierarchy Process)

\section{Background}

The beginning of 2020 witnessed the outbreak of the COVID-19 epidemic and its rapid spread across the world. Most enterprises have made positive contributions to local fights against the epidemic. Nevertheless, some enterprises did something against moral principles, such as making fortune from the epidemic, and ride its wave. For example, some merchants drove up prices of various masks due to consumers' surge demands in the early days of the outbreak. On January 23, 2020, a pharmacy in Fengtai District, Beijing, sold a box of masks with the purchase price of 200 yuan at a ridiculous price of nearly 850 yuan. As a result, the pharmacy was fined 3 million yuan. Some non-conforming enterprises were ordered to suspend business or have their business licenses revoked. There were various reasons behind this phenomenon. On the one hand, the sudden outbreak of the epidemic triggered a strong social sentiment. On this basis, some enterprises made ill-gotten wealth with the public's anxiety. Human beings measure their understandings of a better life from the dimensions of personal wealth, family and interpersonal relationship, as well as national and social environment, according to the "Annual Report on People's Better Life 2019" issued by the Social Psychological Research Center, the Chinese Academy of Social Sciences. People's desire for a better life is associated with national and social factors. In that case, people's mental states and corresponding behaviors become fluctuated and more susceptible to interference from external factors in the face of the co-occurrence of hyperlinks, low integrations, and multiple transformations. Under such a background, the sudden outbreak of the epidemic can easily arouse intense social emotions, thereby affecting consumer behaviors. What's worse, the public's anxiety was aggravated by some enterprises' commercial operations of making fortune from the epidemic utilizing the public's rigid demands of purchasing daily necessities. Some enterprises have misconducted in terms of conforming to the corporate principle and fulfilling CSR under the COVID-19 epidemic. On the other hand, they are some conscientious enterprises that stand a stark compared with those non-performing enterprises. Most enterprises, including Tencent, Alibaba, Wanda, Suning, Huawei, and Ping An, have performed their responsibilities precisely as per their business models in combination with the needs of the epidemic. Furthermore, enterprises shall also actively respond to the economy that is not in full recovery apart from dealing ISSN: 0010-8189

(C) CONVERTER 2021

www.converter-magazine.info 
with the sudden and ongoing epidemic. Hence, various implications are given to enterprises fulfilling CSRs.

\section{Connotation of Corporate Social Responsibility}

Social responsibility underlines society's expectations of an enterprise. Corporate social responsibility, or CSR for short, was proposed by British scholar Oliver Shelton in the book titled" Philosophy of Management" in 1924. Oliver proposed that enterprises shall meet internal and external responsibilities, that is, fulfilling their responsibilities to internal stakeholders and satisfying corporate social responsibility. ${ }^{1}$ The book "Corporate Social Responsibility" edited by Yuan Jiafang in 1990 defined Corporate social responsibility as the company's considerations in social needs and issues in the pursuit of enterprise development, namely, the enterprise shall assume the obligations of safeguarding the fundamental interests of the country, society and human beings. ${ }^{2}$ With the development of the times, CSR has been also endowed with different meanings.

\subsection{Corporate social responsibility evaluation model under the COVID-19 epidemic}

The establishment of a CSR evaluation index system was explored in this paper using the analytic hierarchy process (AHP) under the COVID-19 epidemic. Specifically, the evaluation system is a collection of 16 indexes in five dimensions, including public donation responsibility, responsibility to stakeholders, corporate governance, employee responsibility, and the like. The framework system was constructed in an attempt to explore CSRs that should be assumed by Chinese enterprises under the epidemic.

2.2 Essential factors of the corporate social responsibility evaluation system under the COVID-19 epidemic

\subsubsection{Philanthropic responsibility}

The measurement dimension is principally to evaluate the contribution and demonstration effect of an enterprise to the society under the COVID-19 epidemic. Enterprises, large, small, and medium-sized or micro, should all take active actions during the fight against the COVID-19 epidemic in various forms. Chinese enterprises donated 21.7 billion yuan to the fight against the epidemic as a whole, of which, more than 500 enterprises donated over 10 million yuan; 34 enterprises donated more than 100 million yuan, and 5 enterprises donated more than 1 billion yuan, according to the "White Paper on 2020 China CSR" jointly issued by the Hurun Research Institute and the Guoqiang Public Welfare Foundation. At present, the epidemic situation in China is under control with an incidental risk. Hence, the continuity and effectiveness of the philanthropic activities performed by the enterprise should be also considered in the measurement dimensions. To be concrete, the indexes involve the integrity performance of enterprises, related behaviors of making fortunes from the epidemic, participation in charitable donations of money and goods, effective external donations, the performance of professionalism of the enterprise in the process of conducting public welfare and the presence of corporate social value.

\subsubsection{Responsibility to stakeholders}

As far as stakeholders are concerned, CSR means highlighting the overall benefits of stakeholders while pursuing benefits. ${ }^{4}$ The stakeholders of enterprises, especially the service required by consumers cannot be satisfied timely under the epidemic. It is probably because of the interruption of related industrial chains of the enterprise during the epidemic. Moreover, the results show that $82.5 \%$ of the respondents revealed that they will "have a favorable impression" for the brand contributed to the fight against the COVID-19 epidemic, according to a public survey initiated by the China Corporate Social Responsibility Research Center at Southern Weekly. Therefore, corporate stakeholders propose higher standards for CSR during the epidemic. On this basis, this dimension is mainly measured by the enterprise profitability during the epidemic, whether the enterprise can disclose relevant information to upstream and downstream partners in a timely and complete manner, whether they can assist upstream and downstream partners in the industrial and supply chain, such as proposing a supportive policy or giving certain subsidies for stakeholders. These indexes are applied for measuring an enterprise's fulfillment of CSR to stakeholders.

ISSN: 0010-8189

(C) CONVERTER 2021

www.converter-magazine.info 
2.2.3 Corporate governance responsibility

The measurement dimension is mainly adopted to reflect whether the corporate governance structure can respond to major emergencies in a flexible manner. Specific indexes include: whether the salary distribution mechanism is adjusted under the epidemic, whether senior executives initiatively cut salaries to overcome difficulties together with the company, whether the epidemic can be effectively controlled and prevented inside the enterprise, that is, whether the awareness of epidemic prevention can be effectively raised within the enterprise, such as taking body temperature of employees on a daily basis, whether the supply of epidemic preventing materials can be guaranteed within the enterprise, and whether the enterprise can handle the management of public places, such as timely disinfecting public places.

\subsubsection{Employment responsibility}

These indexes mainly include whether there are layoffs during the epidemic, whether there is a delay in paying salary, such as unpaid vacations during the epidemic, whether employees are allowed to choose places to work, such as whether the remote work is permitted, whether enterprises care the mental health of employees, such as imitatively communicating with employees, paying attention to the information feedback on the employees' mental health, and conducting corresponding mental health counseling. ${ }^{3}$

\subsubsection{Other responsibilities}

The dimension of other responsibilities incorporates whether the enterprise complies with national laws and policies; and whether it receives national, provincial, and municipal government recognition awards related to the content of the evaluation system during the investigation period. These indexes were established for supervising enterprises to be capable of assuming CSR under the COVID-19 epidemic. Hereby, more enterprises are encouraged to initiatively take on the important role of maintaining social stability.

2.3 Weight setting and evaluation methods of the corporate social responsibility evaluation index system under the COVID-19 epidemic

The analytic hierarchy process (AHP) is a systematic method for the target (multi-index) and multi-scheme optimization decision-making through calculating single hierarchical arrangement (weight) and total order sorting on several hierarchies of multiple indexes based on splitting the complex multi-objective decision-making system into multiple goals or criteria. Concrete steps are presented as follows.

2.3.1 Establish a hierarchical structure model of the corporate social responsibility evaluation index system According to the CSR analysis, various factors affecting the CSR evaluation system are classified as per their interrelationships and different attributes, so that several hierarchies were formed in descending order. In principle, each hierarchy shall consist of less than 9 elements. Among them, the highest hierarchy is the general target; hierarchies in the middle is the criteria layer, representing the intermediate link of achieving the target; and the lowest hierarchy is the scheme level, standing for the scheme to achieve the target.

\subsubsection{Determine the judgment matrix}

A judgment matrix was constructed to compare the elements of various levels by pairs according to their relative importance. According to the expert's judgment and the Saaty1-9 scale method, quantitative values of the relative importance of various elements are obtained. Level-1 index judgment matrix is shown in Table 1.

Table 1 Level-1 index judgment matrix given by 5 experts

\begin{tabular}{|l|c|c|c|c|c|}
\hline & $\begin{array}{l}\text { Philanthropic } \\
\text { responsibility } \\
\text { dimension }\end{array}$ & $\begin{array}{l}\text { Stakeholder } \\
\text { responsibility } \\
\text { dimension }\end{array}$ & $\begin{array}{l}\text { Corporate } \\
\text { governance } \\
\text { responsibility } \\
\text { Dimension }\end{array}$ & $\begin{array}{l}\text { Employment } \\
\text { dimension }\end{array}$ & $\begin{array}{l}\text { Other } \\
\text { responsibilities }\end{array}$ \\
\hline $\begin{array}{l}\text { Philanthropic } \\
\text { responsibility }\end{array}$ & 1 & $1 / 3$ & $1 / 4$ & $1 / 2$ & 3 \\
\hline
\end{tabular}

ISSN: 0010-8189 
Volume 2021, No. 5

\begin{tabular}{|c|c|c|c|c|c|}
\hline dimension & & & & & \\
\hline $\begin{array}{l}\text { Stakeholder } \\
\text { responsibility } \\
\text { dimension }\end{array}$ & 3 & 1 & $1 / 3$ & $1 / 2$ & 3 \\
\hline $\begin{array}{l}\text { Corporate } \\
\text { governance } \\
\text { responsibility } \\
\text { dimension }\end{array}$ & 4 & 3 & 1 & 3 & 5 \\
\hline $\begin{array}{l}\text { Employment } \\
\text { dimension }\end{array}$ & 2 & 2 & $1 / 3$ & 1 & 4 \\
\hline $\begin{array}{l}\text { Other } \\
\text { responsibilities }\end{array}$ & $1 / 3$ & $1 / 3$ & $1 / 5$ & $1 / 4$ & 1 \\
\hline
\end{tabular}

The result of the conformity test is

$$
C R=\frac{C I}{R I}=0.0540<0.10
$$

the expert has shown satisfactory conformance, and the weight vector

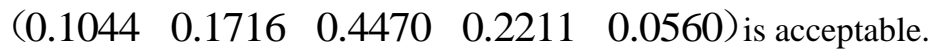

After consultation, it becomes evident that all managers' views are equally important. Combining the advice of five experts, the final weight vector of the first-level index is presented in the following table 2:

Table 2Rating of CSR evaluation index system under the COVID-19 epidemic

\begin{tabular}{|c|c|c|c|c|}
\hline $\begin{array}{l}\text { First-level } \\
\text { index }\end{array}$ & $\begin{array}{l}\text { First-level } \\
\text { index weight }\end{array}$ & Second-level index & $\begin{array}{l}\text { Second-level } \\
\text { index weight }\end{array}$ & $\begin{array}{l}\text { Comprehensive } \\
\text { weight }\end{array}$ \\
\hline \multirow[t]{3}{*}{$\begin{array}{l}\text { Philanthropic } \\
\text { responsibility } \\
\text { dimension }\end{array}$} & \multirow[t]{3}{*}{0.1044} & $\begin{array}{l}\text { Money donations/ goods } \\
\text { donations/ aid in the } \\
\text { construction of epidemic } \\
\text { prevention sites }\end{array}$ & 0.2684 & 0.0280 \\
\hline & & Effective donation & 0.6144 & 0.0641 \\
\hline & & Specialization & 0.1172 & 0.0122 \\
\hline \multirow{3}{*}{$\begin{array}{l}\text { Stakeholder } \\
\text { responsibility } \\
\text { dimension }\end{array}$} & \multirow[t]{3}{*}{0.1716} & Profit & 0.2493 & 0.0428 \\
\hline & & Information disclosure & 0.5936 & 0.1019 \\
\hline & & $\begin{array}{l}\text { Support upstream and } \\
\text { downstream enterprises }\end{array}$ & 0.1571 & 0.0270 \\
\hline \multirow{4}{*}{$\begin{array}{l}\text { Corporate } \\
\text { governance } \\
\text { responsibility } \\
\text { dimension }\end{array}$} & \multirow[t]{4}{*}{0.4470} & $\begin{array}{l}\text { Salary distribution } \\
\text { mechanism }\end{array}$ & 0.545 & 0.2436 \\
\hline & & $\begin{array}{l}\text { Supply of epidemic } \\
\text { prevention materials } \\
\text { within the enterprise }\end{array}$ & 0.2329 & 0.1041 \\
\hline & & $\begin{array}{l}\text { Public place management } \\
\text { within the enterprise }\end{array}$ & 0.1385 & 0.0619 \\
\hline & & $\begin{array}{l}\text { Formulation of an } \\
\text { epidemic prevention plan }\end{array}$ & 0.0837 & 0.0374 \\
\hline \multirow{4}{*}{$\begin{array}{l}\text { Employment } \\
\text { dimension }\end{array}$} & \multirow[t]{4}{*}{0.2211} & Layoff & 0.2754 & 0.0609 \\
\hline & & Delay in payroll & 0.4632 & 0.1024 \\
\hline & & $\begin{array}{l}\text { Flexible choice of office } \\
\text { space }\end{array}$ & 0.0854 & 0.0189 \\
\hline & & Employee mental health & 0.176 & 0.0389 \\
\hline Other & 0.0560 & Fulfill national regulations & 0.6667 & 0.0373 \\
\hline
\end{tabular}

ISSN: 0010-8189

C CONVERTER 2021

www.converter-magazine.info 


\begin{tabular}{|l|l|l|l|l|}
\hline responsibilities & and policies & & \\
\cline { 3 - 5 } & Recognition awards & 0.3333 & 0.0187 \\
\hline
\end{tabular}

Conformity test in total ranking:The total ranking passing through the conformity test.

The dimension of corporate governance responsibility accounts for $44.7 \%$ among the rating of the five major dimensions of the CSR evaluation index system under the COVID-19 epidemic, which appears to be particularly important in comparison with other dimensions. Moreover, the delay in salary, the disclosure of corporate information to stakeholders, and the salary distribution mechanism under the epidemic are also factors essential for evaluating the performance of CSR.

\section{Priority of Enterprises in Fulfilling Corporate Social Responsibilities under the Covid-19 Epidemic}

3.1 Treating employees well to fulfill the corporate social responsibility to employees

Human resources represent primary resources. Enterprises should be more people-oriented under the COVID-19 epidemic, so as to strengthen the cohesion within the enterprise organization. To begin with, the enterprise shall put the safety and health of employees in the first place on the premise of ensuring the basic rights of employees. Enterprises shall convey their concerns with the physical and mental health of employees through various modern communication technologies, manage the health of employees, and appropriately give employees the flexibility to choose a workplace with efforts to retain existing employees. Secondly, the employment mode and salary distribution system of enterprises have been profoundly affected by the epidemic. Hence, enterprises shall consider the cultivation and development of employees from a longer-term and more responsible perspective.

\subsection{Value partnerships and fulfill corporate social responsibility to stakeholders}

Corporate partnerships should be further consolidated under the epidemic. As social responsibilities assumed by enterprises are systematic, long-term, diversified and complex, enterprises should strengthen their partnerships under the epidemic in response to the long-term effect of the uncertain environment. As for consumers, enterprises should avoid driving up prices, hoarding during the outbreak, and not publishing false advertisements to deceive and mislead consumers. As for investors and suppliers, enterprises shall disclose information in a timely and effective manner in face of such force majeure factors. By doing so, stakeholders can share the latest news in time, achieving a mutually beneficial and win-win situation.

\section{Conclusions}

The comprehensive pressure brought by the COVID-19 epidemic has shifted the focus of CSR to philanthropic responsibility, responsibility to stakeholders, corporate governance, employee responsibility, and other five dimensions. In this way, enterprises are required to fulfill their SCRs for creating shared value between the company and stakeholders apart from pursuing efficiency and effectiveness. In such as context, a CSR evaluation index system is established under the COVID-19 epidemic, so as to force and drive enterprises to persist the enterprise's voluntary fulfillment of CSR for a long time.

\section{References}

[1] Sheldon.The Philosophy of Management.The philosophy of management.Sir. I.Pitman,1923.

[2] Yuan Jiafang. Corporate Social Responsibility. Beijing: China Ocean Press, 1990.

[3] Knudsen, J. S. Government Regulation of International Corporate Social Responsibility in the US and the UK: How Domestic Institutions Shape Mandatory and Supportive Initiatives. British Journal of Industrial Relations, 2018, 56: 164 - 188.

[4] Jia Xingping, Liu Yi, Liao Yonghai. Stakeholder pressure, corporate social responsibility and corporate value. Journal of management, 2016,13 (02): 267-274.

ISSN: 0010-8189

(C) CONVERTER 2021

www.converter-magazine.info 